\title{
A Study of Students' and Teachers' Preferences and Attitudes towards Correction of Classroom Written Errors in Iranian EFL Context
}

\author{
Leila Hajian (Corresponding author) \\ Islamic Azad University, Kish International Branch, Kish Island, Iran \\ E-mail: hajianleila@gmail.com \\ Ali Akbar Khomeijani Farahani \\ Faculty of Languages and Literatures, University of Tehran, Tehran, I.R. Iran \\ E-mail: farahani@ut.ac.ir \\ Masomeh Ahmadi Shirazi \\ Faculty of Languages and Literatures, University of Tehran, Tehran, I.R. Iran \\ E-mail: ahmadim@ut.ac.ir
}

Received: 22-04-2014

doi:10.7575/aiac.ijalel.v.3n.5p.287
Accepted: 03-06-2014

Published: 01-09-2014

\begin{abstract}
Written error correction may be the most widely used method for responding to student writing. Although there are various studies investigating error correction, there are little researches considering teachers' and students' preferences towards written error correction. The present study investigates students' and teachers' preferences and attitudes towards correction of classroom written errors in Iranian EFL context by using questionnaire. In this study, 80 students and 12 teachers were asked to answer the questionnaire. Then data were collected and analyzed by descriptive method. The findings from teachers and students show positive attitudes towards written error correction. Although the results of this study demonstrate teachers and students have some common preferences related to written error correction, there are some important discrepancies. For example; students prefer all error be corrected, but teachers prefer selecting some. However, students prefer teachers' correction rather than peer or self-correction. This study considers a number of difficulties regarding students and teachers in written error correction processes with some suggestions. This study shows many teachers might believe written error correction takes a lot of time and effort to give comments. This study indicates many students does not have any problems in rewriting their paper after getting feedback. It might be one main positive point to improve their writing and it might give them self-confidence.
\end{abstract}

Keywords: Error correction, teacher feedback, preferences.

\section{Introduction}

\subsection{Introduce the problem}

It is important for both teachers and students to accept the fact that errors are an inevitable part of the learning process. It is important to investigate L2 students' preferences for teachers' feedback on writing to know whether these preferences match those of their teachers (Diab, 2005). It is through students' error that we can see what they are trying to be, what concepts they have misunderstood and what extra work they might need (Hamouda, 2011).

As second language errors began to be perceived as a necessary and natural process of language learning, learners' errors and feedback to errors have been of great interest to language teachers and researchers (Diab, 2005; Katayama, 2007; Wang, 2010). Most of the studies give more attention to the importance of feedback, ways of providing and receiving feedback as well as what the effect of feedback on students' writing (Lee, 2005; Noora, 2006). What have been neglected in such studies are the preferences and attitudes of the learners and teachers towards error correction (Katayama, 2007).

\subsection{Explore Importance of the Problem}

'Differences in learners' learning styles and preferences affect the learning environment by either supporting or inhibiting their intentional cognition and active engagement" (Katayama, 2007). This stems from the fact that learners are expected to be highly motivated in doing things that they prefer. As such, it is necessary to understand that learners have different preferences i.e. styles in the way they like to be corrected. For instance, some students favor a focus on form while others do not (Hamouda, 2011). 
Some instructors tend to correct all the errors while some tend to be tolerant and still some others do not correct at all (Noora, 2006; Riazi and Riasti, 2007). According to the relevant literature on teachers' and students' preferences and attitudes towards error correction, many studies show that while teachers and students share such common views as the importance of error correction and the types of need correcting, there exist considerable discrepancies as to the techniques of error correction (Lee, 2005; Wang, 2010). For instance, students favor the overall correction, whereas teachers do not. Noora (2006) found that FL students favored a focus on form, but some discrepancies appeared in teachers' beliefs. In a comparison of students' and teachers' beliefs; Diab (2005), also found various discrepancies between EFL instructors' and students' preferences for error correction and paper-marking techniques. Such differences between students' and teachers' expectations and views about feedback can result in unsatisfactory learning outcomes (Katayama, 2007; Riazi and Riasati, 2007).

Accordingly, teachers can benefit from discovering their students' preferences in instructional practices (Hamouda, 2011). Wang (2010, p. 140) proposed that "teachers should find out what their students think and feel about what and how they want to learn". Leki (1991) also points out that an awareness of students' learning styles will enable teachers to adapt appropriate techniques and methods that suit the students' preferences. In addition, matching the learning styles of students in a class and the teaching style of the instructor would help improve students' learning, attitudes, behavior, and motivation (Ferris, 2003). It is, therefore, necessary to find out the ways through which students prefer to be corrected, hoping that such information can help teachers, in general, and Iranian EFL teachers, in particular, to be more effective in their career.

\subsection{The Relevant Literature}

The role of corrective feedback (CF) is still much debated, and is closely related to the conception of the role of different kinds of language input in language acquisition (Doughty \& Williams, 1998). There has been a debate over whether CF is necessary, or even beneficial, for language acquisition. Those who argue against CF claim that positive evidence alone is sufficient for learners to acquire a second language (Krashen, 1982; Schwartz, 1993) and that negative evidence has no use and may even have a harmful effect on inter-language development (Truscott, 1996). Those who advocate $\mathrm{CF}$, argue that negative evidence plays a facilitative and perhaps even crucial role in acquisition. Long's (1996) Interaction Hypothesis claims that implicit negative feedback, arising from negotiation for meaning, provides an opportunity for learners to attend to linguistic form.

The finding of the present study enable English teachers to pay more attention to the way they correct their students' errors to make the students more satisfied with their classes. Without understanding how students feel about and respond to teacher feedback, teachers may run the risk of continually using strategies that are counter-productive (Lee, 2007). Teachers sometimes correct the students without considering what students think of written error correction. Thus in this study we can investigate the source of mismatch existing between teachers' and students' perceptions about written teachers' feedback especially in Iranian contexts.

In conclusion, this study will focus on both teachers' and students' preferences attitudes towards error correction since these attitudes have a great impact on the entire learning process, and then investigate the difficulties of the teachers in providing feedback and of the students in revising the papers after receiving teacher written feedback.

\subsection{The Research Questions}

This study is designed to answer the following research questions:

1- What are the teachers' and students' preferences and attitudes regarding written error correction in Iranian context?

2- What are the difficulties of the EFL teachers in providing feedback and of the EFL students in revising the papers after receiving their teacher's written feedback?

\section{Method}

\section{1 participants}

\subsubsection{Students}

The population of students for the present study should be native Persian speakers, in the Pre-intermediate levels, undergraduates, under 23 years old from Paidar and Tavana Language Institutes. 80 students were selected by simple random sampling method.

\subsubsection{Teachers}

Teacher for this study should teach English at the Pre-intermediate level of the holder institutes, that their experience in teaching English should be 3 or more than 3 years and their age should not be more than 45 . The researcher used 12 teachers by census method.

\subsection{Instrument}

To consider how the teachers and students feel about written error correction, a questionnaire was devised based on the previous studies (Ferris, 2003; Hyland, 2003; Lee, 2003; Radecki and Swales, 1988, cited in Hamouda, 2011). The questionnaire had two major parts that the first part included 51 items dealing with teachers' and students' preferences related to written error correction and the second part was designed to discover the difficulties of the teachers in providing feedback and of the students in revising their papers after given written feedback by their teachers. 
The questionnaire had two versions; the first one was designed for students, and the second one was for teachers that those versions were similar. The questions in the questionnaire were quantified by a Lickert-scale from 1 to 3 ( $1=$ disagree, $2=$ agree, and $3=\mathrm{I}$ do not know). The reliability of the first part was determined using Cronbach's alpha (0.90).

The original version of this questionnaire was designed in English. The final version of the questionnaire was translated into Persian and was presented to the students in both languages to comprehend better the questions and answer them easily. Also it was only presented to the teachers in English version.

\section{Results and Discussions}

\subsection{Data Collection}

To collect data in the present research:

At first, ten students were selected to participate in Pilot study from Pidar and Tavana institutes to answer the questionnaire. Considering the results of the Pilot study, 80 students were selected by the simple randomly sampling method and by Cochran formula.

After that, 12 teachers were selected by Census method from Pidar and Tavana institutes to answer the research questionnaire.

The purpose of focusing on the questionnaire was to discover the teachers' and students' preferences according to written error correction processing and also to explain which difficulties are for both groups on the basis of their opinions.

\subsection{Data Analysis}

Cohen et al. (2007) suggested five ways to present and to investigate the qualitative data:

a) By groups of participants;

b) By individuals;

c) By issues

d) By research questions; and

e) By instrument.

A combination of a) and e) was used in this research to answer the research question that groups of participants included 80 students as one group and 12 teachers as one another group and instrument was the questionnaire given to both groups. Then the frequency of each item was counted and presented in percentages to answer the research questions in present research as clear students' and teachers' views toward written error correction and their difficulties.

\subsection{Research Results}

3.3.1 To answer the first research question, the teachers' and students' preferences regarding written error correction, the results of their preferences are presented in this part.

\subsubsection{Teachers' and Students' Preferences on When to Give Feedback}

According to Table 1, the first item (get feedback at the prewriting stage) was the most important for students in their opinion (77.5\%) and the last item (Item 4: get feedback at the evaluation stage) was the less important for students in their ideas (38.8\%). Items 2 (get feedback at the drafting stage) and item 3 (get feedback at the revising stage) almost were the same for students (Item 2: 65.0\%, Item 3: 63.8\% (See Appendix)).

$75 \%$ of teachers agreed to give feedback at the prewriting and evaluation stage. It was surprising, because by the previous studies, it might have low number of teachers to agree to give feedback in prewriting stage (Item 1 of questionnaire). It might discourage students giving feedback at very early stages of writing (Hamouda, 2011). Although, corrections on composition at final stage might not be suitable to improve students' writing (Stanley, 2003 cited in Hamouda, 2011), many teachers thought to be helpful giving feedback at evaluation stage of writing in this study (Item 4 of questionnaire). $58.3 \%$ of teachers agreed to give feedback at drafting stage. Although, according to the previous studies, giving feedback in drafting stage might be better than evaluation stage (Stanley, 2003 cited in Hamouda, 2011), there were a little more than half of number of teachers agreed to give feedback at drafting stage (Item 2). $41.7 \%$ of teachers agreed to give feedback at revising stage (Item 3).

\subsubsection{Teachers' and Students' Preferences on Color of Pen Used to Give Feedback}

Table 2 demonstrated using a red pen has got the highest agreement of both students (with $75 \%$ ) and teachers (with $91.7 \%$ ) as compared to using a pencil with $23.8 \%$ agreement by students and with $8.3 \%$ agreement by teachers. As the previous studies, many students believed that when their teachers do not apply a red pen, they do not do their responsibility to help their students learning well (Lee, 2005). So, students thought a red pen can be more effective than pencil and also, teachers thought using a red pen helps students to understand better.

\subsubsection{Teachers' and Students' Views Regarding the Amount of Teacher Written Correction}

According to Table 3,70\% of students believed that all error of their writing should be corrected, $33.8 \%$ of them thought to select some errors, but just $8.8 \%$ of them agreed to not correct any error. So, like the previous researches (Leki, 1991; Oladejo, 1993; Halimi. 2008; Lee, 2005; and Diab, 2005) many of students (in this study: 70\%) like their 
teachers to correct all errors in their papers and they like to correct all errors to be comprehended for them rather than select some as selective error correction to avoid any confusing point.

Table 3 showed $50 \%$ of teachers preferred to correct all errors of their students' writing. Correcting all errors of students' writing might not lead to the good impact on students' self-awareness and it might lead students just to copy their teachers' correction on their papers without any careful attention (Katayama, 2007). 66.7\% of teachers agreed to select some errors. Thus, they thought it would be better to select some and leave the rest with suggestions for students to correct (Hamouda, 2011). Also none of teachers agreed to correct no error.

\subsubsection{Teachers' and Students' Preferences Regarding to the Issue of Who Do the Correction}

Based on Table 4, a large number of students (87.5\%) believed that error correction by their teachers might be useful and helpful (Item 10). As same finding from Radecki and Swales (1988), many of students prefer to be corrected by their teachers because they believed it is their teachers' responsibilities. It might be because of the students trust their teachers so they preferred to have error correction by their teachers. In contrast to Item 10 , just $17.5 \%$ of students agreed to be corrected by their peer (Item 11). Students might be afraid to receive bad feedback from their peers, so they were uncomfortable with peer correction (Oladejo, 1993). More than half of students agreed to correct their errors themselves (Item 12). It might be glad for them (Diab, 2005). However, they preferred their teachers to correct their errors rather than self- or peer-correction.

$83.3 \%$ of teachers preferred to correct written errors by teachers. $58.3 \%$ of teachers agreed to correct written errors by students' peers. And also, 58.3\% of teachers believed that students should correct themselves. So, teachers believed errors correction is important and those three groups should be trying to correct errors and they might play a necessary role to correct errors.

\subsubsection{Teachers' and Students' Preferences for Forms of Paper-marking Techniques}

Based on Table 5, Item 14 of questionnaire (See in Appendix) was selected by $91.7 \%$ of teachers. So, they agreed to correct their students' errors in writing by statements. It was surprising, in contrast with the results of the previous studies. Statements might be hard for teachers to express their ideas in completed sentences (Hamouda, 2011).

$83.3 \%$ of teachers agreed to use exclamations (Item 17) and also, $83.3 \%$ of them preferred to cross out the error and writing the correct word or structure (Item 18). The percentages of those two items are similar. The preference for the use of exclamations, teachers might try to help their students' improvements for comparing two drafts. And it was surprising, teachers' agreements by $83.3 \%$ about crossing out the error and writing in the correct word or structure, in contrast with the results of previous studies: the EFL teachers might not prefer crossing out what is incorrect and writing the correct word or structure as the best technique to mark errors in a first draft (Diab, 2005; Hamouda, 2011).

$75 \%$ of teachers agreed to correct students' errors in writing by writing questions (Item 13). Although, in previous studies, writing questions as feedback on the students' writing might lead to confusion or misunderstanding (Hamouda, 2011). There are agreements of $75 \%$ of teachers. $66.7 \%$ of teachers agreed understanding the error and write comments at the end of the essay (Item 15). 58.8\% of teachers preferred using correction codes (Item 19). They believed using correction codes might make students think of the mistakes and know their types of mistakes. 50\% of teachers preferred using imperatives (Item 16). Although half of the number of teachers agreed to use imperatives, imperatives might be confusing.

But Item 15 and Item 18 corrected of the questionnaire were with the same and highest percentage (60\%) of agreement from students. So, students preferred that their teachers understand their errors and write their comments at the end of the essay and also liked their teachers cross out their error and write in the correct word or the correct structure. Then, students selected Item 14 more than others with $58.8 \%$ agreements to get paper-marking technique by statement. Item 13 was selected with $53.8 \%$ of students to have questions forms of paper-marking techniques by their teachers to know their errors in their writings.

After that, Item 16 and Item 19 corrected of the questionnaire were selected as $35 \%$ agreement by students. It means $35 \%$ students preferred to use imperatives by their teachers to give feedback about their error and also $35 \%$ of them preferred to use correction codes from their teachers to correct their written errors. It was surprising that Item 19 with less than half number of students (35\%) agreed to use correction codes shown using correction codes were not preferred by $65 \%$ of students. Or Item 16 was with just $35 \%$ agreement from students. Students might think they might be confused by using imperatives form of paper-making techniques because of less support in helping them to rewriting their writings. And at last, $31.3 \%$ of students preferred Item 17. So they preferred to use exclamations by their teachers to give them error correction feedback.

\subsubsection{Aspect(s) in Writing Teachers and Students Prefer Teachers' Comments Focus on}

Table 6 investigated $72.5 \%$ of students selected to correct grammar (Item 20). So, the highest attention to correct different parts of sentences was grammar. $67.5 \%$ of students preferred content (Item 23). So, they thought content in writing is more important and those kinds of error should be corrected by teachers and their teachers' comments on this part are necessary. Item 22 of questionnaire was important for $57.5 \%$ of students. Those students believe vocabulary is important to receive feedback from their teachers. After that, spelling and punctuation errors (Item 21) were important for $47.5 \%$ of students. They would prefer to get their teachers' feedback on mechanics of their writing. Finally, Item 24 of questionnaire was less important than others for students with 42.5\%. Item 24 was about organization and paragraph construction errors. 
This finding was surprising. Mechanics, organization and construction were selected by less than half of the number of students. So students would prefer to pay little attention to those aspects and it was unexpected. Previous studies show that students would prefer to get teachers' comments on grammatical, lexical and mechanics aspects more than those on content and construction (Halimi, 2008; Hamuoda, 2011). Also it may cause different results, even by the same students for example in the results of Diab (2005) asking about these features from students by three tables (6 items and 18 subitems), at first most of them agreed to point out errors in grammar by teachers in both first draft and final draft $(86 \%$ agreements for first draft and $82 \%$ agreements for final draft, but in item 6, grammar was one of the minimal percentages in students' responses and it just was more than spelling and punctuation (See Diab, 2005).

But, $100 \%$ of teachers agreed that teachers' comment should be focused on grammar (Item 20). So, all of them believed grammatical errors should receive the most attention and feedback on grammar should be at all stages of writing. 91.7\% of teachers believed vocabulary choice was needed teachers' feedback more (Item 22). And also, 91.7\% of teachers chose content was needed more teachers' feedback (Item 23). So, according to results from Table 6, Items 22 and 23 were similar noticeable with teachers' percentages. $75 \%$ of teachers selected mechanics to be noticed by teachers' feedback (Item 21). And also, 75\% of teachers thought that organization and paragraph construction should be noticed by teachers giving comments on their students' writing (Item 24).

\subsubsection{Teachers' and Students' preferences for types of feedback}

$68.8 \%$ students preferred positive comments more than other types of feedback (Item 27). So, most students answered to positive comments. Also, positive feedback might encourage and motivate students. $67.5 \%$ of students preferred detailed and specific comments (Item 26). Generally, detailed and specific feedback is more effective than the general feedback to suggest feedback more clearly (Hamouda, 2011). 46.3\% students believed that direct feedback might be helpful (Item 29). Direct comments might increase motivation in students to improve students' self-confidence to correct their errors (Wang, 2010). 45\% students preferred to receive end feedback from their teachers (Item 32). Then, there were $42.5 \%$ students preferred general comments (Item 25). Also, this percentage was much less than detailed and specific comments. $40 \%$ of students preferred indirect feedback (Item 30), then, 32.5\% students selected margin feedback (Item 31), after that, finally, 28.8\% the students chose negative comments (Item 28).

$91.7 \%$ of teachers preferred to give positive comments (Item 27). And also, $91.7 \%$ of teachers agreed to give direct comments (Item 29). Related to Item 26 of Table 7 of the questionnaire, detailed and specific comments were important with $75 \%$ of teachers as same as percentages for indirect feedback, Item 30 of Table 7 of questionnaire (75\%). $66.7 \%$ of teachers preferred end feedback to their students' writing (Item 32). They thought end feedback is valued more. Table 7 demonstrated the similar agreements for Items 28 and 31 of Table 7 of questionnaire with teachers' percentages (58.3\%). So, $58.3 \%$ of teachers chose negative comments and also margin feedback. $50 \%$ of teachers agreed to apply general comments to students' writing (Item 25).

\subsubsection{Teachers' and Students' Views Regarding What Students Usually Do after Reading Their Teachers' Comments}

Based on Table $8,82.5 \%$ of students agreed to like to read every mark/comment their teachers wrote on their pieces of work carefully. It means more than two thirds of students liked to read every mark/comment their teachers wrote on their pieces of work carefully (Item 33 of Table 8 of questionnaire). $77.5 \%$ of students agreed to ask their teachers for help (Item 35 of Table 8 of questionnaire). It might be help to solve their confusion, misunderstanding or incomprehensive problems (Hamouda, 2011). 75\% of students like to go to the library to consult reference materials (e.g. grammar books, dictionaries) for Item 38 of Table 8 of the questionnaire. They might think dictionary is helpful for students.

$61.3 \%$ of students prefer to ask their classmates to help them. So, Item 39 of Table 8 of questionnaire was useful by students' opinions. It might be easier, comfortable and not fearful to connect with their classmate. More than half of students (52.5\%) were mostly concerned and motivated about the grade (Item 34). So, the grade was important for students to improve their writing. $43.8 \%$ of students agreed to make correction themselves (Item 40) as same as using the internet to find more references (Item 37). Using the Internet to find more references indicated that the students have the skills to utilize such kinds of helpful and useful resources in enhancing their papers (Hamouda, 2011). 33.8\% of students chose Item 41 of Table 8 of questionnaire. So, they prefer to ignore their errors, because they thought that they do not how to make the corrections. It also might be related to their fear of remake their errors or mistakes. $31.3 \%$ of students do not like to read the entire composition again after their teachers have marked it (Item 42). So, more than two thirds of students like to read over their composition. Just $27.5 \%$ of students preferred to ask other teachers to help them (Item 36). Although, many people think that students do that, doing this way might deal with more problems.

But, $91.7 \%$ of teachers agreed that students are mostly concerned and motivated about the grade (Item 34). Although, this result was similar with Hamouda's (2011) result, this result was in contrast with Halimi's (2008). Halimi (2008), said none of the participants like to work just to receive good grade and no more aim (Hamouda, 2011). And also, Table 8 showed one percentage with $91.7 \%$ of teachers for Item 41 of Table 8 of questionnaire too. So, they thought that students ignore their errors because they do not know how to make the corrections. $83.3 \%$ of teachers believed that students ask their teacher for help (Item 35). So, they viewed teachers as authorities who can offer help (Hamouda, 2011). $75 \%$ of teachers agreed with this point that students ask their classmates for help (Item 39). Students are not afraid of their classmates anymore. And also, $75 \%$ of teachers agreed with Item 42 of Table 8 of questionnaire. So, they thought that students do not like to read the entire composition again after their teachers have marked them. 
$66.7 \%$ of teachers believe that students go to the library to consult reference materials (e.g. a grammar book, a dictionary) (Item 38). 58.3\% of teachers agreed that students like to read every mark/comment their teacher wrote on their piece of work carefully (Item 34). They might think that students read their teachers' comments carefully. And also, $58.3 \%$ of teachers thought students use the Internet to find more reference (Item 37) and Item 40 of Table 8 of the questionnaire with $58.3 \%$ of teachers that believed that students should make correction themselves. $41.7 \%$ of teachers agreed that students may ask some other teachers to help (Item 36).

\subsubsection{Students' and Teachers' Preferences on When to Give Feedback}

Table 9 demonstrated $78.8 \%$ of students agreed that their teachers' comments and corrections help them to know what to avoid/improve next time and to know where their mistakes are and correct them. So, they believed their teachers' feedback might be useful and helpful for them (See Appendix). Based on Table 9, 77.5\% of students agreed that the feedback given make them want to try harder to improve in their writing. $77.5 \%$ of students agreed that they feel that their writing have improved because of the feedback given on their paper. Table 9 indicated $72.5 \%$ of students believed that they enjoy the teachers' comments on their composition (Item 45). $71.3 \%$ of students liked the way their composition is marked, generally (Item 51). 61.3\% of students thought the feedback given make them feel good about themselves (Item 49). 41.3\% of students agreed their teachers' comments are too general (Item 44). And just 10\% of students agreed to Item 43 of Table 9 of questionnaire. So, $80 \%$ of them believed that their teachers' comments are not too negative and discouraging.

According to results from Table 9, students were happy to get their teachers' feedback on their writing (similar to result of Lee, 2005; Diab, 2005; Hamouda, 2011). They might trust their teacher. So, they thought their teachers' feedback might be necessary for them to improve their writing.

Table 9 showed all teachers $(100 \%)$ believed that teachers' comments and corrections help students to know where mistakes are and correct them (Item 47). 91.7\% of teachers agreed that teachers' comments and corrections help students to know what to avoid/improve next time (Item 46). And also, 91.7\% of teachers selected Item 45 of Table 9 of questionnaire. Teachers like their own comments given to students. $83.3 \%$ of teachers agreed that giving feedback makes students want to try harder to improve in their writing (Item 48). 83.3\% of teachers believed that students feel that their writings have improved because of the feedback given on their paper (Item 50). 41.7\% of teachers chose Item 51 of Table 9 of questionnaire. So, they liked the way the composition is marked. Just 33.3\% of teachers believed teachers' comments are too general (Item 44). And 50\% of them did not accept comments given by teachers are too general. Low numbers of teachers (16.7\%) thought teachers' comments are too negative and discouraging (Item 43) therefore, $83.3 \%$ of them thought teachers' feedbacks are not too negative and discouraging.

3.3.2 To answer the second research question, the difficulties of teachers in providing feedback and of students in revising the papers after receiving teachers' written feedback, the results of their ideas are presented in this part.

\subsubsection{What Are the Difficulties of the Teachers in Providing Feedback?}

To consider this part of second research question, there was Table 10 of questionnaire designed especially for teachers (See Appendix). So, they could choose one or more than one as they thought as their difficulties in providing feedback.

It was not surprising that many teachers chose part (a) as main part of difficulties in providing because of result of previous studies (Hamouda, 2011; Leki, 1991). It may take a long time for teachers to read, respond, and comment on students' writing (Hamouda, 2011; Leki, 1991). After part (a) there were part (b) and (e) chosen by teachers more important as difficulties in providing. It was no surprising that they selected part (b) because it may be time-consuming, but it was surprising about part (e) was selected by teacher and its' percentage was as same as part (b)'s percentage because based on previous studies, there was assumed that there might be narrow space to write a long feedback so the student had problem to right understanding (Stannard, 2008). But, by Table 4.21 these two items were similar in importance $(33.3 \%)$.

Last two parts (parts (c) and (d)) had the same result regarding their percentages, so it means they were similar in importance to teachers' difficulties in providing feedback. The results of some previous studies showed that teachers believed that by many mistakes or errors in students' writing, it might not be reasonable for teachers to correct or give comment to them and it might be time- and effort- consuming (Gulcat and Ozagac, 2004; Hamouda, 2011). Table 10 demonstrates that only $25 \%$ of teachers selected part (c) which was different from the previous study showed importance of students' mistake as teachers' difficulties to give useful and helpful feedback. It was not worrying issue for $75 \%$ of teachers involved in the present study. However, it was problematic for teachers that students just see their grades on their writings and abandons their papers (Leki, 1991), part (d) just took the concern of 25\% of teachers involved this research and they might think students read their comments about their writing carefully and improve their writing by those feedbacks.

Too surprising about this part of questionnaire was that $25 \%$ of teachers did not select none of these five parts and their reason were not clear and it may be one limitation of the present study that main part especially for one group (teachers) of study may not be sensitive for $25 \%$ of them. So, it was better, if the teachers were asked to explain the reason of their selection or to say other difficulties more than these items. Or it was helpful if they were asked to attend in an oral interview after answering the questionnaire. However, it is not possible to find all difficulties of teachers to give comments or feedback to their students' written error, teachers wanted to know their students' aim about their feedback. 
3.3.2.2 What Are the Difficulties of the Students in Revising the Paper After Receiving Their Teachers' Written Feedback?

To investigate this part of second research question, Table 11 of research questionnaire was applied to discover students' opinion about difficulties that students had in revising the paper after receiving their teachers' written feedback. So, there are considering all items in this part. Students could select one or more than one of these items as they believed.

$52.5 \%$ of students (part (a) of Table 11) did not have problems in revising their papers after getting feedback. It might be because of their high self-confidence and it was one main positive point to improve their writing easily after their teachers gave comments to their paper and also they know the advantages of their teachers' feedback to help to improve their writing processes including prewriting, drafting, and revising stages. $31.3 \%$ of students (part (d) of Table 11) were afraid of making new mistakes. By previous studies, it might happen because of students' carelessness, students' habit of making these kinds of mistakes, or misunderstanding about teachers' corrections or comments (Hyland, 2003; Stannard, 2008 cited in Hamouda, 2011). So, this study showed that students' afraid of making new mistakes was the largest difficulties in revising their writing after getting teachers written feedback. Revising grammatical and mechanical errors (part (b) of Table 11) was more difficult than others in the opinion of $28.8 \%$ of students. It might be because of those students' weakness grammatically or mechanically or might be inabilities of their teachers to give correct comments.

$26.3 \%$ of students believed that they do not have enough time to revise the drafts (part (f) of Table 11). It might be because of weakness of students to revise their writing or teachers' incomprehensible feedback and it might lead to have students confused by wasting their much time. It was number of students facing this difficulty by $26.3 \%$ unfortunately.

Table 11 showed number of students to have problems with their teachers' feedback on their writing with $23.8 \%$ of students (part (e) Table 11). It might be because of less awareness of students about their teachers' written feedback so, it caused misunderstanding by students and it was not useful to improve their writing. So, teachers should try more to avoid happening these misunderstanding by explain about their students' errors clearer by their correct and clear comments. $20 \%$ of students chosen part (1) as one problematic point to improve their writing, it related to their weakness or their misunderstanding about written feedback given by their teachers again so it was really important for students to notice more by teachers and was necessary for them to improve in revising their writing after receiving the teacher written feedback because $20 \%$ of those students worried about facing with this difficulty.

Unlike grammatical difficulties in Table 11, just $16.3 \%$ of students (part (c) of Table 11) selected difficulties of revising content and expression suggested by their teachers. So, it was problematic for less number of students rather than grammatical problems. It might be caused from teachers' abilities to give right comments related these errors to their students to revise their contents and expressions mistakes easily. It might be the students trusted their teachers and they understood what their teachers wanted and expected by their teachers' feedback and it was hopeful for this part.

Based on Table 11, part (g) of Table 11 of questionnaire, the students did not think having large number of mistakes to revise except for $15 \%$. Although, it was discouraging students of revising their writing (Gulcat and Ozagac, 2004 cited in Hamouda, 2011), other students did not choose this part, had high self-confidence by their writing to revise them easily and it might be helpful to have good revising and good result of writing at the end of writing processes. Last part of this study with $11.3 \%$ percentage was part (h) (part (h) of Table 11). It means less number of students thought their teachers' written feedback was uselessness (11.3\%). It was hopeful for their teachers to know that students believed their teachers' feedback were helpful to improve revising their paper.

Although, some parts were chosen as problematic of written processing by large numbers of students, it was hopeful to have a good relationship between students and their teachers trustfully according for example: parts $\mathrm{c}$ and $\mathrm{h}$. It was one student had no comment to these nine parts.

\section{Conclusions and Implications of the Study}

\subsection{Summary of Results}

Results from this study demonstrate that difficulties for both groups with regard to written error correction are important. Focus on awareness about teachers' and students might help to be facilitated doing written error correction processing. For example; when teachers believe giving feedback on error correction takes a lot of their time, awareness of their students' fear of making errors and their less time to revising can demonstrate them that their students are trying improve their writing by trying trust them and their comments. So, the co-relation between teachers and their students could help to improve writing for students and avoid consuming their time by decreasing their misunderstanding and mismatching about written error correction.

Also, by this study, and also by the questionnaire presented to students, students might be aware of different stages of writing and the importance of their teachers' comments during those stages to improve their writing and also, their awareness decreases their stress about their errors. It was interesting that the same ideas from teachers and students about feedback on first stage of writing was reported, and also that the teachers did not agree to let students' brainstorm grow up. Teachers are aware of the necessity of feedback at final stage (evaluation stage), although, students do not read teachers' feedback in this stage.

Students believed, if their teachers give feedback or do paper-marking by using red pen, the reason might be the teachers' self-confidence, and if they do not use red pen, they do not do their job and assume their responsibilities well. 
Also, the teachers know their students' views related to red pen. Their percentage about red pen is similar. As students' preferences, it is better if teachers correct all the errors (comprehensive). As teachers' preferences, it is better if teachers select some errors (selective). However, both of them did not prefer if teachers do not correct any error. Students preferred error correction by teachers more than their peers' and self-correction. Teachers thought three groups (teachers, peers, and students themselves) could correct class errors. According to students' preferences, writing comments at the end of the essay and crossing out the error and writing in the correct word or structure were more useful than other form of paper-marking techniques. But, teachers preferred using statements more.

Although all aspects in writing were important for the teacher, all teachers focused on grammatical errors to give feedback for. Less than two thirds of students believed to get comments on their grammatical errors. A large number of teachers preferred positive and direct feedback. Students preferred positive, detailed and specific comments more than others on their writing. A large number of students liked to read every teacher comments on their writing carefully, but just a little more than half a number of teachers believed students do this work. Most of teachers looked at the grade as motivation for students, but a little more than half a number of students thought so. Although teachers thought that students ignore them because they do not know how to make the corrections, there was just one thirds of students agreeing with that.

Teachers and students believed that teacher feedback might improve students' writing.

\subsection{Implications of the Study}

\subsubsection{Implications for Teaching}

Firstly, results of present study show that teachers' view related to grammatical errors are influenced by their ideas about how they give feedback. So, personal philosophies affected on teachers' written error feedback. Therefore, it may be argued that there may be a need for reflection on the teachers' part to become more conscious regarding the written error correction strategies they utilize. Teachers might develop reflective and useful comments as strategies to improve written error correction. So, according to the findings of this study, teachers provide written error correction in agreement with their views. The implication may be that teachers should be able to use their written error correction strategies with students' needs and their weakness related to their writing.

Secondly, it appears from the findings of the questionnaire for students, they were afraid of making mistakes and they were worried about their abilities to correct their grammatical errors. Teachers have to try to improve their students' self-confidence to overcome their fears according to written error correction. Teachers should try to avoid confusion and misunderstanding on the part of the students. It might be helpful combining different strategies of feedback related to written error correction.

Thirdly, for improving written error correction, teachers need to have enough time. This finding suggests teachers need to spend extra time providing written feedback. Implication of the findings is that teachers should integrate their lesson plans to have adequate time to correct written errors and give suitable feedback. Also, teachers should be clearer with their students regarding their written error correction strategies from the first stages of writing.

Finally, by the findings, it is important that which types of feedback teacher prefer related to written error correction. The implication is that teachers should be certain that the types of feedback that they are applying are helpful for writing needs of students.

\subsubsection{Implications for Teacher Training}

As teachers give feedback and comments or correct errors based on their thought, their education syllabus might be related to their opinion. So, it is better to require their syllabus regarding to the results of this study. This study shows where the students' and the teachers' ideas might be different. Thus, it is necessary to know the students' opinion to have a suitable syllabus.

To enhance written error correction strategies effectively, teachers should apply strategies that might improve students writing by making students aware of their views.

Adequate time for every activity should be noticed by teachers in their syllabus. It might happen by focus on students' weakness according to writing. It might happen by using self-confidence and self-evaluation strategies in syllabus by teachers. Teachers may improve their ability mentally and physically even if they know the needs of their students or awareness of appropriate written feedback strategies related to those needs. So, having useful syllabus may help teachers become more aware of everything that impacts their written feedback for students. And also, it avoids consuming their time.

\subsection{Suggestions for Further Research}

Firstly, data from participants (teachers and students) in the present study were collected by questionnaire. By questionnaire, there were some ambiguities in some cases; for example, some teachers did not choose any item of Table 10 of questionnaire, although, they knew this part was for discovering teachers' difficulties to give feedback, it is not clear why they did not answer this part. So, it might be helpful to use other data collection methods such as interviews combining questionnaire to receive more suitable information regarding the present study.

Secondly, due to time limitation, the participants in this study were limited to only two groups (12 teachers and 80 students). Students' level was pre-intermediate level. They were under 23 years old. It would be an ideal research to imply questionnaire on larger number of participants, with varying ages, and different English proficiency levels. This 
limitation of the present study suggests that future research could investigate a larger group of participants in order to increase the possibility of producing a more generalized result with a richer degree of information related to teachers' and students' preferences towards written error correction.

\section{References}

Cohen, L., Manion, L., \& Morrison, K., (2007). Research Methods in Education, Routledge.

Diab, R. L. (2005). EFL university students' preferences for error correction and teacher feedback on writing TESLvReporter, 38, 27-51. From https: //ojs.lib.byu.edu/spc/TESL/article/view File/3809/3555.

Doughty, C., \& Williams, J. (1998). Focus on form in classroom second language acquisition. Cambridge: Cambridge University Press.

Ferris, D. R. (2003). Response to Student Writing: Implications for Second Language Students. New Jersey:Mahwah. Lawrence Erlbaum Associates Publishers, 50-51.

Gulcat, Z., \& Ozagac, O. (2004). Correcting and giving feedback to writing. Retrieved Dec. 12, 2008. From https://www.buowl.boun.edu.tr/teachers.

Halimi, S.S. (2008). Indonesian teachers' and students' preferences for error correction. Wacana, 10 (1), 50-71.

Hamouda, A.(2011). A study of students and teachers preferences and attitudes towards correction of classroom written error in Saudi EFL context. English Language Teaching, 4 (3), 128-141. From https://www.ccsenet.org/efl. doi:10.5539/efl.v4n3p128. ISSN 1916-4742 E-ISSN 1916-4750.

Hyland, K. (2003). Focusing on form: student engagement with teacher feedback. System, 31, 217-230. From https://dx.doi.org/10.1016/S0346-251X(03)00021-6, DOI: 10.1016/S0346-251X(03)00021-6.

Katayama, A.(2007). Japanese EFL students' preferences toward correction of classroom oral errors. Asian EFL Journal, 9 (4), 290-306. From https://www.asian-efl- journal.com/Dec-2007-ak.php

Krashen, S. (1982). Principles and practice in second language acquisition. Oxford: Pergamon Press.

Lee, I. (2003). L2 writing teachers' perspectives, practices and problems regarding error feedback. Assessing Writing, 8, 216-237. .

Lee, I. (2005). Error correction in the L2 writing classroom: what do students think? TESL Canada

Journal/Revue TESL Du Canada, 22 (2). From https://www.teslcanadajournal.ca/index.php/tesl/article/veiw/84.

Lee, I. (2008). Understanding teachers' written feedback practices in Hong Kong secondary classroom. Journal of Second Language Writing, 17, 69-85.

Leki, I. (1991). The preferences of ESL students for error correction in college-level writing classes. Foreign

Language Annals, 24, 203-218.

Long, M. (1996). The role of the linguistic environment in second language acquisition. In W.R. Richie, \& T.J.

Bhatia, (Ed.), Handbook of second language acquisition (pp. 413-468). Diego, CA: Academic Press.

Noora, A. (2006). Iranian Non-English Majors' Language Learning Preferences: The Role of Language Institutes.

Developing Teach. From https://www.asian-efl-journal.com/site-map.php.

Oladejo, J.A. (1993). Error correction in ESL: Learner's preference. TESL Canada Journal, 10 (2), 71-89.From

http://www.teslcanadajournal.ca/index.php/tesl/article/view/619/450

Radecki, P. M., \& Swales, J.M. (1988). ESL student reaction to written comments on their written work. System, 16, 355-365.

Riazi,A., \& Riasati, M. (2007). Language Learning Style Rreferences: A Student's Case Study of Shiraz EFL Institutes. Asian EFL Journal.

Schwartz, B.D. (1993). On explicit and negative data effecting and affecting competence and linguistic behavior. Studies in Second Language Acquisition, 15, 147-163.

Stanley, J. (1992). Coaching student writers to be more effective peer evaluators. Journal of Second Language Writing, 1 (3), $217-233$.

Stannard, J. (2008). A new direction in feedback. Retrieved Dec. 20, 2008. From https://www.hltmag.co.uk/dec08/mart04.htm

Truscott, J. (1996). The case against grammar correction in L2 writing classes. Language Learning, 46 (2), 327-369.

Wang, P. (2010). Dealing with English majors written errors in Chinese universities. Journal of Language Teaching and Research, 1(3), 194-205. From https://www.academypublisher.com/ojs/index.php/jltr/article/view File/1797. ISSN $\underline{1798-4769 .}$.

\section{Appendix}

Table1. Teachers' and students' preferences on when to give feedback

\begin{tabular}{|c|c|c|c|c|c|c|c|c|c|c|c|c|}
\hline \multirow[t]{2}{*}{ I prefer to give the feedback } & \multicolumn{6}{|c|}{ Students } & \multicolumn{6}{|c|}{ Teachers } \\
\hline & 1 & $\%$ & 2 & $\%$ & 3 & $\%$ & 1 & $\%$ & 2 & $\%$ & 3 & $\%$ \\
\hline 1) At the prewriting stage & 11 & 13.8 & 62 & 77.5 & 7 & 8.8 & 1 & 8.3 & 9 & 75 & 2 & 16.7 \\
\hline 2) At the drafting stage & 19 & 23.8 & 52 & 65 & 9 & 11.3 & 3 & 25 & 7 & 58.3 & 2 & 16.7 \\
\hline \begin{tabular}{|ll} 
3) & At the revising stage \\
\end{tabular} & 19 & 23.8 & 51 & 63.8 & 10 & 12.5 & 5 & 41.7 & 5 & 41.7 & 2 & 16.7 \\
\hline 4) At the evaluation stage & 41 & 51.3 & 31 & 38.8 & 8 & 10 & 2 & 16.7 & 9 & 75 & 1 & 8.3 \\
\hline
\end{tabular}


Table2. Color of pen that teachers and students would like teachers to give feedback

\begin{tabular}{|c|c|c|c|c|c|c|c|c|c|c|c|c|}
\hline \multirow{2}{*}{$\begin{array}{l}\text { In giving feedback, I like teachers to } \\
\text { use ... }\end{array}$} & \multicolumn{6}{|c|}{ Students } & \multicolumn{6}{|c|}{ Teachers } \\
\hline & 1 & $\%$ & 2 & $\%$ & 3 & $\%$ & $\mathbf{1}$ & $\%$ & 2 & $\%$ & 3 & $\%$ \\
\hline 5) The red pen & 14 & 17.5 & 60 & 75 & 6 & 7.5 & 0 & 0 & 11 & 91.7 & 1 & 8.3 \\
\hline 6) The pencil & 52 & 65 & 19 & 23.8 & 9 & 11.3 & 9 & 75 & 1 & 8.3 & 2 & 16.7 \\
\hline
\end{tabular}

1=disagree, 2 = agree, $3=$ I do not know.

Table3. Students' and teachers' views regarding to the amount of teacher written

\begin{tabular}{|c|c|c|c|c|c|c|c|c|c|c|c|c|}
\hline \multirow[t]{2}{*}{ It would be better if teachers... } & \multicolumn{6}{|c|}{ Students } & \multicolumn{6}{|c|}{ Teachers } \\
\hline & $\mathbf{1}$ & $\%$ & 2 & $\%$ & 3 & $\%$ & $\mathbf{1}$ & $\%$ & 2 & $\%$ & 3 & $\%$ \\
\hline 7) Correct all the errors & 18 & 22.5 & 56 & 70 & 6 & 7.5 & 6 & 50 & 6 & 50 & 0 & 0 \\
\hline 8) Select some errors & 44 & 55 & 27 & 33.8 & 9 & 11.3 & 2 & 16.7 & 8 & 66.7 & 2 & 16.7 \\
\hline 9) Do not correct any error & 59 & 73.8 & 7 & 8.8 & 14 & 17.5 & 11 & 91.7 & 0 & 0 & 1 & 8.3 \\
\hline
\end{tabular}

1=disagree, 2 = agree, $3=$ I do not know.

Table4. Students' and teachers' views regarding the issue of who will do the correction

\begin{tabular}{|c|c|c|c|c|c|c|c|c|c|c|c|c|}
\hline \multirow[t]{2}{*}{ It would be better if teachers... } & \multicolumn{6}{|c|}{ Students } & \multicolumn{6}{|c|}{ Teachers } \\
\hline & $\mathbf{1}$ & $\%$ & 2 & $\%$ & 3 & $\%$ & 1 & $\%$ & 2 & $\%$ & 3 & $\%$ \\
\hline 10) The teacher & 4 & 5 & 70 & 87.5 & 6 & 7.5 & 0 & 0 & 10 & 83.3 & 2 & 16.7 \\
\hline 11) Students'peers & 57 & 71.3 & 14 & 17.5 & 9 & 11.3 & 5 & 41.7 & 7 & 58.3 & 0 & 0 \\
\hline 12) Students (self-correction) & 31 & 38.8 & 42 & 52.5 & 7 & 8.8 & 4 & 33.3 & 7 & 58.3 & 1 & 8.3 \\
\hline
\end{tabular}

1=disagree, 2 = agree, $3=$ I do not know.

Table5. Students' and teachers' preferences for forms of paper-marking techniques

\begin{tabular}{|l|l|l|l|l|l|l|l|l|l|l|l|l|}
\hline $\begin{array}{l}\text { How would you like teachers to correct } \\
\text { students' errors in writing? }\end{array}$ & \multicolumn{1}{|c|}{ Students } & \multicolumn{6}{|c|}{ Teachers } \\
\hline & $\mathbf{1}$ & $\%$ & $\mathbf{2}$ & $\%$ & $\mathbf{3}$ & $\%$ & $\mathbf{1}$ & $\%$ & $\mathbf{2}$ & $\mathbf{3}$ & $\mathbf{3}$ \\
\hline 13) writing questions & 24 & 30 & 43 & 53.8 & 13 & 16.3 & 2 & 16.7 & 9 & 75 & 1 & 8.3 \\
\hline 14) statement & 21 & 26.3 & 47 & 58.8 & 12 & 15 & 0 & 0 & 11 & 91.7 & 1 & 8.3 \\
\hline $\begin{array}{l}\text { 15) understanding the error and write } \\
\text { comments at the end of the essay }\end{array}$ & 20 & 25 & 48 & 60 & 12 & 15 & 3 & 25 & 8 & 66.7 & 1 & 8.3 \\
\hline 16) using imperatives & & & & & & & & & & & & \\
\hline 17) using exclamations & 40 & 50 & 28 & 35 & 12 & 15 & 5 & 41.7 & 6 & 50 & 1 & 8.3 \\
\hline $\begin{array}{l}\text { 18) crossing out the error and writing in } \\
\text { the correct word or structure }\end{array}$ & 40 & 50 & 25 & 31.3 & 15 & 18.8 & 2 & 16.7 & 10 & 83.3 & 0 & 0 \\
\hline 19) using correction codes & 23.8 & 48 & 60 & 13 & 16.7 & 1 & 8.3 & 10 & 83.3 & 1 & 8.3 \\
\hline
\end{tabular}

1=disagree, 2 = agree, $3=$ I do not know.

Table6. Focus on feedback that students and teachers would like

\begin{tabular}{|l|l|l|l|l|l|l|l|l|l|l|l|l|}
\hline Which aspect(s) in writing would you & \multicolumn{4}{|c|}{ Students } & \multicolumn{5}{|c|}{ Teachers } \\
prefer teachers' comment to focus on? & $\mathbf{1}$ & $\%$ & $\mathbf{2}$ & $\%$ & $\mathbf{3}$ & $\%$ & $\mathbf{1}$ & $\%$ & $\mathbf{2}$ & $\%$ & $\mathbf{3}$ & $\%$ \\
\hline 20) grammar & 12 & 15 & 58 & 75.5 & 10 & 12.5 & 0 & 0 & 12 & 100 & 0 & 0 \\
\hline 21) mechanics (e.g.punctuation, spelling & 27 & 33.8 & 38 & 47.5 & 15 & 18.8 & 3 & 25 & 9 & 75 & 0 & 0 \\
\hline 22) vocabulary choice & 22 & 27.5 & 46 & 57.5 & 12 & 15 & 1 & 8.3 & 11 & 91.7 & 0 & 0 \\
\hline 23) content & 15 & 18.8 & 54 & 67.5 & 11 & 13.8 & 1 & 8.3 & 11 & 91.7 & 0 & 0 \\
\hline $\begin{array}{l}\text { 24) organization and paragraph } \\
\text { construction }\end{array}$ & 35 & 43.8 & 34 & 42.5 & 11 & 13.8 & 2 & 16.7 & 9 & 75 & 1 & 8.3 \\
\hline
\end{tabular}

1=disagree, 2 = agree, $3=$ I do not know.

Table7.Students' and teachers' preferences for types of feedback

\begin{tabular}{|l|l|l|l|l|l|l|l|l|l|l|l|l|}
\hline \multirow{2}{*}{$\begin{array}{l}\text { Which type of teacher comments do } \\
\text { you prefer? }\end{array}$} & $\mathbf{1}$ & $\mathbf{6}$ & $\mathbf{2}$ & $\mathbf{6}$ & $\mathbf{3}$ & $\mathbf{0}$ & $\mathbf{1}$ & $\mathbf{\%}$ & $\mathbf{2}$ & $\%$ & $\mathbf{3}$ & $\%$ \\
\hline 25) general comments & 32 & 40 & 34 & 42.5 & 14 & 17.5 & 6 & 50 & 6 & 50 & 0 & 0 \\
\hline 26) detailed and specific comments & 16 & 20 & 54 & 67.5 & 10 & 12.5 & 3 & 25 & 9 & 75 & 0 & 0 \\
\hline 27) positive comments & 11 & 13.8 & 55 & 68.8 & 14 & 17.5 & 1 & 8.3 & 11 & 91.7 & 0 & 0 \\
\hline 28) negative comments & 43 & 53.8 & 23 & 28.8 & 14 & 17.5 & 5 & 41.7 & 7 & 58.3 & 0 & 0 \\
\hline 29) direct feedback & 29 & 36.3 & 37 & 46.3 & 14 & 17.5 & 1 & 8.3 & 11 & 91.7 & 0 & 0 \\
\hline 30) indirect feedback & 32 & 40 & 32 & 40 & 16 & 20 & 3 & 25 & 9 & 75 & 0 & 0 \\
\hline 31) margin feedback & 37 & 46.3 & 26 & 32.5 & 17 & 21.3 & 5 & 41.7 & 7 & 58.8 & 0 & 0 \\
\hline 32) end feedback & 30 & 37.5 & 36 & 45 & 14 & 17.5 & 4 & 33.3 & 8 & 66.7 & 0 & 0 \\
\hline
\end{tabular}

1=disagree, 2 = agree, $3=$ I do not know.

Table8. Students' and Teachers' views regarding what students usually do after they read their teacher's comments and corrections

\begin{tabular}{|l|l|l|l|l|l|l|l|l|l|l|l|l|}
\hline $\begin{array}{l}\text { What do students usually do after they } \\
\text { read their professor's comments and } \\
\text { corrections? }\end{array}$ & $\mathbf{1}$ & $\%$ & $\mathbf{2}$ & $\mathbf{6}$ & $\mathbf{3}$ & $\mathbf{0}$ & $\mathbf{1}$ & $\%$ & $\mathbf{2}$ & $\%$ & $\mathbf{3}$ & $\%$ \\
\hline $\begin{array}{l}\text { 33) Students like to read every } \\
\text { mark/comment their teacher wrote on } \\
\text { their piece of work carefully. }\end{array}$ & 2 & 2.5 & 66 & 82.5 & 12 & 15 & 5 & 41.7 & 7 & 58.3 & 0 & 0 \\
\hline $\begin{array}{l}\text { 34) Students are mostly concerned and } \\
\text { motivated about the grade. }\end{array}$ & 23 & 28.8 & 42 & 52.5 & 15 & 18.8 & 1 & 8.3 & 11 & 91.7 & 0 & 0 \\
\hline
\end{tabular}


IJALEL 3(5):287-297, 2014

\begin{tabular}{|l|l|l|l|l|l|l|l|l|l|l|l|l|}
\hline 35) Students ask their teacher for help. & 6 & 7.5 & 62 & 77.5 & 12 & 15 & 2 & 16.7 & 10 & 83.3 & 0 & 0 \\
\hline $\begin{array}{l}\text { 36) Students ask some other teacher for } \\
\text { help }\end{array}$ & 47 & 58.8 & 22 & 27.5 & 11 & 13.8 & 7 & 58.3 & 5 & 41.7 & 0 & 0 \\
\hline $\begin{array}{l}\text { 37) Students use the internet to find } \\
\text { more reference. }\end{array}$ & 34 & 42.5 & 35 & 43.8 & 11 & 13.8 & 4 & 33.3 & 7 & 58.3 & 1 & 8.3 \\
\hline $\begin{array}{l}\text { 38) Students go to the library to consult } \\
\text { reference materials (e.g. grammar book, } \\
\text { dictionary). }\end{array}$ & 12 & 15 & 60 & 75 & 8 & 10 & 4 & 33.3 & 8 & 66.7 & 0 & 0 \\
\hline $\begin{array}{l}\text { 39) Students ask their classmates for } \\
\text { help. }\end{array}$ & 18 & 22.5 & 49 & 61.3 & 13 & 16.3 & 4 & 33.3 & 8 & 66.7 & 0 & 0 \\
\hline $\begin{array}{l}\text { 40) Students make correction } \\
\text { themselves. }\end{array}$ & 33 & 41.3 & 35 & 43.8 & 12 & 15 & 5 & 41.7 & 7 & 58.8 & 0 & 0 \\
\hline $\begin{array}{l}\text { 41) Students ignore them because they } \\
\text { do not know how to make the } \\
\text { corrections. }\end{array}$ & 40 & 50 & 27 & 33.8 & 13 & 16.3 & 3 & 25 & 9 & 75 & 0 & 0 \\
\hline $\begin{array}{l}\text { 42) Students don't like to read the entire } \\
\text { composition again after their teachers } \\
\text { have marked them. }\end{array}$ & 44 & 55 & 25 & 31.3 & 11 & 13.8 & 7 & 58.3 & 5 & 41.7 & 0 & 0 \\
\hline
\end{tabular}

\section{1=disagree, 2 = agree, $3=$ I do not know.}

Table 9. Students' and teachers' views regarding how students feel about their teacher comments

\begin{tabular}{|l|l|l|l|l|l|l|l|l|l|l|l|l|}
\hline $\begin{array}{l}\text { How do you feel about teachers' } \\
\text { comments? }\end{array}$ & \multicolumn{3}{|c|}{ Students } & \multicolumn{3}{|c|}{ Teachers } \\
\hline $\begin{array}{l}\text { 43) Teacher's comments are too } \\
\text { negative and discouraging. }\end{array}$ & 64 & 80 & 8 & 10 & 8 & 10 & 10 & 83.3 & 2 & 16.7 & 0 & 0 \\
\hline $\begin{array}{l}\text { 44) Teacher's comments are too } \\
\text { general. }\end{array}$ & 36 & 45 & 33 & 41.3 & 11 & 13.8 & 6 & 50 & 4 & 41.3 & 2 & 16.7 \\
\hline $\begin{array}{l}\text { 45) I enjoy the teacher's comments on } \\
\text { composition. }\end{array}$ & 10 & 12.5 & 58 & 72.5 & 12 & 15 & 1 & 8.3 & 11 & 91.7 & 0 & 0 \\
\hline $\begin{array}{l}\text { 46) Teacher's comments and } \\
\text { corrections help students to know what } \\
\text { to avoid / improve next time. }\end{array}$ & 7 & 8.8 & 63 & 78.8 & 10 & 12.5 & 0 & 0 & 11 & 91.7 & 1 & 8.3 \\
\hline $\begin{array}{l}\text { 47) Teacher's comments and } \\
\text { corrections help students to know } \\
\text { where mistakes are and correct them. }\end{array}$ & 7 & 8.8 & 63 & 78.8 & 10 & 12.5 & 0 & 0 & 12 & 100 & 0 & 0 \\
\hline $\begin{array}{l}\text { 48) The feedback given makes students } \\
\text { want to try harder to improve in their } \\
\text { writing. }\end{array}$ & 8 & 10 & 62 & 77.5 & 10 & 12.5 & 1 & 8.3 & 10 & 83.3 & 1 & 8.3 \\
\hline $\begin{array}{l}\text { 49) The feedback given makes students } \\
\text { feel good about them. }\end{array}$ & 26 & 32.5 & 49 & 61.3 & 5 & 6.3 & 3 & 25 & 8 & 66.7 & 1 & 8.3 \\
\hline $\begin{array}{l}\text { 50) Students feel that their writing } \\
\text { have improved because of the feedback } \\
\text { given on their paper. }\end{array}$ & 10 & 12.5 & 62 & 77.5 & 8 & 10 & 1 & 8.3 & 8 & 66.7 & 3 & 25 \\
\hline $\begin{array}{l}\text { 51) Generally, I like the way the } \\
\text { composition is marked. }\end{array}$ & 13 & 16.3 & 57 & 71.3 & 10 & 12.5 & 0 & 0 & 10 & 83.3 & 2 & 16.7 \\
\hline
\end{tabular}

\section{1=disagree, 2 = agree, 3 = I do not know.}

Table 10.Teachers' difficulties in providing feedback

\begin{tabular}{|l|l|}
\hline \multicolumn{1}{|c|}{ Problems } & Number of mentions \\
\hline a. It takes a lot of time and effort to give comment. & $5=41.7 \%$ \\
\hline b. There are too many papers to mark. & $4=33.3 \%$ \\
\hline c. Students make too many mistakes. & $3=25 \%$ \\
\hline d. Students don't read teachers' comments; they only look at the mark given. & $3=25 \%$ \\
\hline e. Students don't understand the feedback. & $4=33.3 \%$ \\
\hline
\end{tabular}

Table11. Difficulties of the students in revising the papers after receiving feedback

\begin{tabular}{|c|c|}
\hline Problems & Number of mentions \\
\hline a. I do not have any problems in rewriting my paper after getting feedback. & $42=52.5 \%$ \\
\hline b. I can't correct all the grammatical and mechanic mistakes that the teacher points out. & $23=28.8 \%$ \\
\hline c. I can't revise the content and the expressions suggested by the teacher. & $13=16.3 \%$ \\
\hline d. I am afraid of making other new mistakes. & $25=31.3 \%$ \\
\hline e. I don't understand the teacher written feedback. & $19=23.8 \%$ \\
\hline f. I don't have sufficient time to revise the drafts. & $21=26.3 \%$ \\
\hline g. I have too many mistakes to revise. & $12=15 \%$ \\
\hline h. The teacher written feedback is not always helpful. & $9=11.3 \%$ \\
\hline 1. I don't know how to rewrite the papers even after receiving the teacher written feedback. & $16=20 \%$ \\
\hline
\end{tabular}

